NBER WORKING PAPER SERIES

\title{
LARGE BLOCK SHAREHOLDERS, INSTITUTIONAL INVESTORS, BOARDS OF DIRECTORS AND BANK VALUE IN THE NINETEENTH CENTURY
}

\author{
Howard Bodenhorn \\ Working Paper 18955 \\ http://www.nber.org/papers/w18955
NATIONAL BUREAU OF ECONOMIC RESEARCH
1050 Massachusetts Avenue
Cambridge, MA 02138
April 2013

I thank Henry Hansmann and Mariana Parglender for sharing an early draft of their 2012 working paper. Eric Hilt and Danielle Zanzalari offered helpful comments on an earlier draft. The views expressed herein are those of the author and do not necessarily reflect the views of the National Bureau of Economic Research.

NBER working papers are circulated for discussion and comment purposes. They have not been peerreviewed or been subject to the review by the NBER Board of Directors that accompanies official NBER publications.

(C) 2013 by Howard Bodenhorn. All rights reserved. Short sections of text, not to exceed two paragraphs, may be quoted without explicit permission provided that full credit, including $\odot$ notice, is given to the source. 
Large Block Shareholders, Institutional Investors, Boards of Directors and Bank Value in the Nineteenth Century

Howard Bodenhorn

NBER Working Paper No. 18955

April 2013

JEL No. G3,N21

\begin{abstract}
Share prices of modern corporations are influenced by the size and structure of boards of directors, large individual and institutional investors, and shareholder voting rights, among other governance features. It is not clear whether the same features mattered historically, given recent research suggesting that the principal concern in the nineteenth century was neither managerial self-dealing nor majority shareholder expropriation that might reduce the returns to common shareholders. Rather, at many nineteenth-century corporations, common shareholders were also customers and shareholding offered preferential access to the firms' goods and services. Using modern empirical tools in a study of banks, this study finds evidence supporting the shareholder-as-customer model. Bank values responded positively to the presence of large-block individual shareholders (those more concerned with access to loans) and negatively to large-block institutional investors (those more concerned with dividend returns than access). Moreover, firm value declined as directors consumed larger fractions of a bank's loans, which reduced the bank's ability to extend credit to other shareholders.
\end{abstract}

Howard Bodenhorn

John E. Walker Department of Economics

College of Business and Behavioral Science

201-B Sirrine Hall

Clemson University

Clemson, SC 29634

and NBER

bodenhorn@gmail.com 


\title{
Large Block Shareholders, Institutional Investors, Boards of Directors and
}

\author{
Bank Value in the Nineteenth Century
}

\section{Introduction}

Which governance characteristics of a firm influences its value? The modern finance literature identifies board size and composition, large institutional investors, large block indivdual shareholders, CEO power and share voting rights, among others, as governance features that influence firm value. Although the literature provides insights into contemporary connections between corporate governance practices, firm policies and market value, our understanding of the history of corporate governance remains rudimentary. It is not yet clear that historical corporate governance operated like its modern counterpart. It is also not yet clear whether historical market actors assessed and reacted to governance features like their modern counterparts. Conceptions of the corporation as political and economic organizations have evolved over the past two centuries, so it is likely that governance policies have evolved as well.

This study contributes to an incipient literature that investigates how applicable modern approaches to corporate governance are to the early days of the corporation. ${ }^{1}$ Using newly constructed data on the governance features at early US banks, I find some parallels between historical and contemporary corporate governance and its effects on bank performance. One historical feature - the number of members of the board of directors - has comparable historical and modern effects. Larger

${ }^{1}$ Principal contributors to the literature include Freeman, Pearson and Taylor (2012), Guinnane et al (2007), Harris (2009), Hilt (2008), Hansmann and Parglender (2012), Lamoreaux (2009) and Musacchio (2009). 
boards are associated with lower nineteenth-century bank value (measured by Tobin's Q). Firm size and free cash flow influence bank value in predictable ways. Any parallel between the historical and modern firm breaks down, however, when considering the influence of large block individual and institutional shareholders. Nineteenth-century bank value is predicted to increase when an individual holds at least a 5\% stake in the firm, a finding consistent with the Shleifer and Vishny (1986) contention that large block shareholders monitor and discipline management. But historical bank value declines in the presence of a 5\% block institutional shareholder. That the effects of large individual and institutional shareholdings influence bank value in opposite ways suggest that the historical connection between large shareholdings and firm value do not have straight-forward modern parallels.

Freeman, Pearson and Taylor (2012) and Hansmann and Parglender (2012) contend that the nineteenth-century bank was less profit-oriented firm concerned primarily with maximizing shareholder wealth and more of a loan club or mutual organization. Shareholders owned shares in anticipation of dividends or capital gains, of course, but the principal motivation behind owning bank shares was that ownership conferred preferential access to credit. Share prices moved with changes in the benefits of access. Issues of endogeneity inevitable arise and several estimation techniques are used to address endogeneity and identify causal effects. Estimates are robust to the inclusion of additional controls and to the endogenizing of some variables treated as exogenous in the baseline results. The results are consistent with the contention that historical corporate governance features influenced bank value, but not necessarily in the same way that they influence outcomes in the modern world.

The data used in this study are from mid-nineteenth century Massachusetts so questions of representativeness inevitably arise. The institutional milieu in which Massachusetts' banks operated make them a suitable and useful laboratory for exploring the connection between bank governance structures, portfolio choices, dividend policies, and firm value in the nineteenth century. Massachusetts 
banks, while not representative of banking generally in the nineteenth century US, was representative of banking in the Northeastern and Middle-Atlantic regions, which was the most financially developed region of the county at that time. Massachsuetts bank law, too, was relatively liberal and it chartered banks freely (Sylla, Wallis and Legler 1987). State law afforded banks substantial leeway in several governance features, such a board size and dividend policies, that were mandated by corporate charter in other states. Massachusetts law, for example, provided that banks have between five and 13 directors. In short, Massachusetts banks were provided relatively wide latitude in operating policies, which provides sufficient variation to capture the consequences of choices. The latitude afforded its banks in several important dimensions of governance policy makes it a useful laboratory to investigate their historical import.

\section{Investors, monitors and other determinants of firm value}

\subsection{Large investors}

A world in which ownership and control are separated and in which managers fail to maximize profits (and firm value) is a world in which profit opportunities exist for an effective monitor to take control of a firm and replace existing managers with ones whose preference for profits align with the monitor's. Small shareholders do not have a large enough stake in a firm to bear the costs of monitoring and disciplining management. Outsiders who might be able to monitor and discipline are dissuaded from buying enough shares to implement their plans because small shareholders demand a price for their shares that reflects expected increases in firm profitability. The disciplinarian, therefore, captures only a fraction of the increase in firm value attributable to her activities. The fundamental issue then, as Shleifer and Vishny (1986) present it, is that a plan for improving corporate performance is a public good, which is under-provided by the market. 
Can the under-provision of monitoring and discipline problem be overcome? Or, are corporations characterized by separation of ownership and control doomed to underperform? Shleifer and Vishy (1986) argue that the public goods problem is partly overcome if shareholders already holding a large fraction of a firm's shares (hereafter "blockholders") provide some of the public good. Monitoring and discipline remain under-provided relative to a theoretical optimum, but the extent of self-serving managerial behavior is mitigated. This capacity for blockholders to improve corporate profitability explains, in part, why blockholding is common (Demsetz and Lehn 1985; Shleifer and Vishny 1986; Bethel, Liebeskind and Upler 1998).

Replacing underperforming managers is no simple matter, however. Jarrell, Brickley and Netter (1988) discuss the many defensive measures that can be raised against corporate takeovers and Shleifer and Vishny (1986, p.477) simplify the disciplinarian role by assuming that one or more current passive blockholders may become activist if managerial self-dealing pushes firm profitability below some threshold. Corporate takeover is not the only disciplinary mechanism; blockholders may be able to engage in proxy fights and oust incumbent managers without buying additional shares. If the blockholder can seat enough directors sympathetic to her concerns, management can be changed. ${ }^{2}$

A further complication arises if not all blockholders have the same incentives. Brickley, Lease and Smith (1988) identify affiliated blockholders, or those with existing or potential business ties with the firm, and unaffiliated blockholders, or those without. Because affiliated blockholders expect the value

${ }^{2}$ In the case of nineteenth-century banks, a proxy fight was probably not much of a fight. In 1860s Massachusetts an average of 15 shareholders attended the annual meeting and voted fewer than 540 shares, or just $12 \%$ of outstanding shares. Moreover, $12 \%$ percent of a bank's shares represented less than $12 \%$ of the votes due to so-called graduated voting rules that restricted the number of votes allotted to blockholders (Hilt 2008; Bodenhorn 2012). Mounting a successful proxy fight would not have required forming a large coalition of like-minded shareholders. Staggered boards were not used as a defense mechanism. Massachusetts banking law required every director to stand for annual election. See Bebchuk and Cohen (2005) and Duru, Wang and Zhao (2013) for discussion of the economics of staggered boards. 
of an existing business tie to decline in the face of managerial turnover, they are more likely to side with current management than with an activist blockholder looking to replace management and change policy. ${ }^{3}$

Affiliated blockholding was a real issue at nineteenth-century banks. Lamoreaux (1994) and Lamoreaux and Glaisek (1991) find that New England banks often extended the lion's share of their loans to founders, directors and other blockholders. Lamoreaux considers the practice to have been economically benign, if not efficient, in that insiders were often related by kinship ties, were well informed about each other's business abilities and prospects, served to check excessive lending, and limited each other's risk-taking (see also Meissner 2005). Such extensive affiliated lending presumably affected firm value positively or negatively depending on the perceived quality of loans made to the firm's investors/borrowers and the extent to which large blockholders might monopolize a bank's lending at the expense of minority shareholders. Pargendler and Hansmann (2012), Hansmann and Pargendler (2012) and Freeman, Pearson and Taylor (2012), in fact, contend that the principal corporate governance issue of the era was not that of blockholders expropriating minority owners or managerial shirking, but of blockholders monopolizing a bank's credit at the expense of minority shareholders. Banks were more loan clubs (or mutuals) than modern commercial banks. The model shareholder was a customer, though the customer base usually extended beyond shareholders.

Two questions present themselves. First, were banks really loan clubs? Lamoreaux's research suggests that banks, while not pure loan clubs per se, were financial arms of extended kinship business networks, the financial enterprises of New England mercantile and manufacturing keiretsus. Shareholders and other insiders took up a large fraction of the banks' loans. Freeman, Pearson and

${ }^{3}$ Borokhovich et al (2006) further separate blockholders into activist and passive (or nonactivist) types. Activist blockholders are those who seek to alter managerial policy. 
Taylor $(2012,118)$ find the same for Britain, where bank bylaws sometimes set explicit caps on shareholder borrowing equal to a fraction of the value of the shares they held. The wisdom of this practice was widely debated at the time, mostly because bank promoters needed to assuage third party stakeholders, notably depositors and noteholders, concerned with the security and liquidity of their debt. If shareholders were to be customers, it was important to attract the right kind of shareholders.

Second, how would the share prices of loan clubs differ, if at all, from share prices of commercial banks? If bank shareholders were investors in the classic sense, then share prices would be determined by Gordon’s (1959) dividend discount model: or

$$
P=d /(r-g)
$$

where $\mathrm{P}$ is the current price; $\mathrm{d}$ is the value of the next (or most recent) dividend; $\mathrm{r}$ is the constant cost of equity; and $\mathrm{g}$ is the expected permanent constant growth rate in dividends. For simplicity assume the growth rate is zero, which is consistent with the empirical regularity that mature banks tended to smooth dividends over time (Bodenhorn 2003).

If nineteenth-century banks were loan clubs in the sense that shareholders and other insiders received credit on preferential terms, then the motive for ownership was different and dividends may not have been the driving force behind share prices. If preferential credit access has any meaning, it is that for given loan characteristics the loan club offers loans to members at lower rates than insiders would expect to receive from an arm's-length lender. That is, for a loan $\mathrm{L}(\mathbf{F})$ of size $\mathrm{L}$ and risk characteristics $F$, the club member pays an interest rate $i_{\mathrm{lc}}<i^{*}$, where $i^{*}$ represents the market rate. The club member's benefits of share ownership are then any dividend received plus the expected interest savings $\left(i^{*}-\dot{1}_{l}\right) \times L(F)$, so the share price of a loan club bank is then determined by:

$$
P=\left[d+\left(i^{*}-i_{l}\right) \times L\right] / r
$$

assuming for simplicity that the growth rate of dividends and interest rates are both zero. Pargendler 
and Hansmann (2012) contend that governance policies, notably shareholder voting rights, in early nineteenth century were designed so that loan club members did not have to fret over the possibility that the bank would fall under the control of one or more majority shareholders that would monopolize the bank's credit. Graduate voting rights also reduced the likelihood that the bank would fall under the control of unaffiliated investors more interested in dividends than credit access. The fact is that nineteenth-century banks were hybrid institutions, part loan club and part profit-oriented corporations. Shareholders borrowed, but not every shareholder borrowed in every period. Moreover, banks paid regular, non-trivial dividends.

It is reasonable to think that shareholders with a bank-as-loan-club preference did not want to tie up their capital in bank shares. The loan-club model in fact presupposes that these shareholders could not self-finance their market activities at their preferred scale. It was incumbent on loan-club shareholders then to raise outside capital, presumably from shareholders who would not compete with them for the bank's credit. Otherwise, internal competition between shareholder-customers would have driven internal interest rates to the market rate. But to attract unaffiliated shareholders, the shareholdercustomers were forced to pay dividend that yielded a competitive, risk-adjusted return on the investor's capital. This meant that loan-club members paid more than the marginal cost (=average variable cost) of credit and/or, the loan-club extended enough loans to nonshareholders at market rates to generate profits that could be distributed as dividends to unaffiliated shareholders.

Affiliated shareholders thus had to offer a market return in dividends to unaffiliated shareholders while maintaining a credit cost savings for themselves sufficient to reimburse the opportunity cost of capital invested in bank shares. At any time an existing blockholder might turn dividend-seeking activist, support the election of one or more board members, threaten to replace management and transform the loan club into a commercial bank. Loan club members would not 
necessarily suffer a capital loss from the takeover, and certainly not if the transition increased the share price, but they would then borrow at rates closer to market rates. As Hansmann and Pargendler (2012) note, governance provisions that are often interpreted as investor protections may be better viewed as consumer protections in the case of investor-consumer loan clubs. A share voting rule, for example, that limited or capped the number of votes cast by blockholders (votes $<$ shares) protected club members from loss of credit privileges.

It is less clear what effects a transition from loan club to profit seeking (and dividend paying) would have on share prices and firm value. Increased dividends would attract investors which, all else equal, would drive share prices up. But club members, having lost access to credit, would sell out to invest in another loan club. If club members sell en masse, share prices decline. Absent a strong logical prior, determining the net effects of investor blockholders and individual blockholders on firm value is then an empirical question explored below.

\subsection{Institutional investors}

Since the 1980s, institutional investors - most notably mutual funds and pension funds such as CREF and CALPERS - have become large, if not the largest investors in US corporations, which has led scholars to better understand the consequences of concentrated institutional ownership (Gillan and Starks 2000; Chen, Harrod and Li 2007). Because institutional investors differ from atomistic individual investors in their ability to collect and analyze information and monitor managers, they are thought capable of altering corporate governance and corporate behaviors. Theoretically, institutional investors adopt one of three roles: they actively monitor management, they passively monitor, or they cooperate with management.

Under the active-monitoring scenario, large institutional investors have incentives and the 
expertise to monitor managers, do so at a lower cost than atomistic shareholders, improve firm performance and, therefore, firm value (Shleifer and Vishny 1986; Woidtke 2002; Chen Harrod and Li 2007). Because they hold a large fraction of a firm's shares they can influence a firm's actions. And, if institutional investments are durable and stable, investors have more incentives and more opportunities to learn about the firms they invest in (Elyasiani and Jia 2010). Because stable institutional investors have long horizons, their interest in the value of and returns on their own portfolios encourage them to discipline management more so than short-horizon traders. Large institutional investors are thought to enhance firm value.

The leading institutional investors in nineteenth-century bank shares were insurance companies and savings banks who purchased bank shares less for the value of becoming affiliated and gaining access to credit than to earn a return through dividends. Insurance companies invested client premiums as reserves against future claims; savings banks invested deposits in securities to provide small depositors with a safe haven for their money and a modest return. ${ }^{4}$

Although directors at insurance companies and savings banks may have leveraged their directorships at these firms into a preferred customer relationship with a bank, dividend returns were the principal motivation behind share holdings and insurance companies held diversified share portfolios. In 1858 each of Massachusetts's 90 insurance companies held an average of 1418.8 shares in 14.3 banks. They also invested in railroad shares (306.0 shares in 3.3 railroads on average, with a mode of 0 shares in 0 firms), railroad bonds, manufacturing company shares, and made secured and

\footnotetext{
${ }^{4}$ Rules governing insurance company investments were fairly lax: insurers could generally "purchase, hold and convey any estate, real or personal, for the use of the company." Savings banks were given similarly wide latitude in their investments. The deposits of the Institute for Savings in Roxbury, for example, were to be "used and improved to the best advantage of the owners thereof;" and in 1825 Boston's Provident Institution for Savings charter was amended so that its directors could subscribe shares in any newly incorporated bank (Private and Special Acts 1837, 260263).
} 
unsecured loans to borrowers. In 1860 bank shares made up 21.4 percent of Massachusetts's savings banks' total assets. ${ }^{5}$ Savings banks relied on dividends from bank shares to diversify the risks of personal lending and to pay competitive returns to their depositors.

Although some individual shareholders viewed the nineteenth-century bank as a loan club, institutional investors considered them dividend-generating entities. As the principal institutional investors, insurance companies and savings banks held bank shares for the expected returns from the shares. If disagreements emerged among classes of shareholders over bank practices and policies, they were likely to have arisen between individual and institutional shareholders. Evidence of different objectives and the tensions they created for directors in balancing the demands of customers and investors is likely to appear in different effects of large institutional shareholdings and large individual shareholdings on firm value. Different objectives among broad classes of shareholders may have played out in the selection and retention of directors, but the sources do not afford an investigation of this possibility. The sources, however, allow for an investigation of how institutional and individual blockholders influenced board size, a feature of concern in modern corporate governance studies.

\section{$\underline{2.3 \text { Board size and structure }}$}

The modern literature identifies five basic responsibilities of boards of directors: (1) they select, evaluate, and replace the bank's president, CEO, and other managers; (2) they review and approve strategic decisions; (3) they provide advice and counsel to management; (4) they establish election

${ }^{5}$ Unlike the insurance reports, which listed the number of shares of individual banks held by each insurance company, the annual savings bank reports provided only aggregate dollar values of shares held. Loans on mortgage and other collateral made up the bulk of the savings banks' earning asset portfolios. Savings bank investments afforded their depositors a competitive return. Of the 39 savings banks reporting in 1860, 33 reported that they paid a 5 percent or greater dividend the previous year; 17 reported having returned an average 7 percent or greater dividend over the previous five years. 
procedures for successors; and (5), they review compliance with laws and regulations (Linck, Netter and Yang 2008). Nineteenth-century bank boards were expected to provide the same functions. In Massachusetts, bank charters and general banking laws laid down the basic rules for boards consistent with responsibilities (1), (2), (4) and (5). The State Bank of Boston's 1811 charter, for example, provided that the directors would "choose one of their own number to act as President" and establish his salary. The directors would also choose the cashier (CEO and COO), demand from him a bond with appropriate sureties, and determine his compensation (Massachusetts General Court 1812). Every six months the directors determined the amount of the semi-annual dividend, if any. Each year the board was to advertise the place and time of the annual, stockholders meeting and supervise the election of the next year's directors. Every six months the directors were to transmit a balance sheet to the legislature and governor and they were personally liable if the bank's managers violated certain regulations.

With respect to the third listed responsibility (advice and counsel), nineteenth-century bank directors were also much more engaged in the firm's daily operations than many modern directors. Board meetings to consider loan requests were held as often as three days each week. At the typical board meeting the cashier read the names of the applicants, the amounts requested, and whether the applicant "kept a good, middling, or small account" at the bank (Wainwright 1953, 19). Boards usually imposed limits on loan sizes based on average account balances, and rationed credit based on each applicant's reputation. The latter influence was so important, in fact, that board members were usually chosen based on their knowledge of local businessmen's characters, activities, prospects and abilities. Some bank bylaws required unanimous consent of a quorum of the board; some instituted black ball systems to preserve anonymity in loan approvals; some allowed the cashier to make small, run-of-themill loans and reserved for themselves prior approval of large loans or loans to unfamiliar applicants. 
In addition to their regular duty of approving loans, board committees were regularly appointed to inspect the books, count the monies in the vault, and meet with representatives from other banks to discuss such wide-ranging topics as the value at which foreign coins or banknotes would be accepted, how to prosecute counterfeiting, and the terms under which new entrants would be allowed into existing clearing arrangements. Nineteenth-century bank boards worked hard, but they were typically not directly compensated for their time. Instead, it was understood that board members, like other shareholders, would receive preferential credit terms and nineteenth-century bank board members borrowed, often substantial amounts (Lamoreaux 1994).

Given the workload expected of them and the nature of the remuneration, bank boards influenced firm value. The quality and influence of individual members provided signals to informed investors about a bank's prospects, but the most easily observed board characteristic for most investors was its size. There is no general equilibrium theory of board size and structure, but there is consensus in the literature that optimal board size and structure is based on the costs and benefits of the board's monitoring and advising roles (Pathan and Skully 2010). Acting in their role of monitor, boards supervise and restrain managers from self-serving behaviors. Acting in their advising role, boards provide strategic guidance.

Following Yermack (1996), most studies posit that, ceteris paribus, larger boards are less effective than smaller ones. Compared to smaller ones, large boards may be subject to shirking, face greater coordination costs, provide less timely advice, monitor less effectively, or become dysfunctional in other dimensions. Larger boards are generally associated with lower firm value (Yermack 1996). Smaller may not always be better, however. Complex firms, large firms, and those with greater debtequity ratios place greater advising demands on directors and may be better served by larger boards. Coles, Daniel and Naveen (2008) find that smaller boards are value enhancing for small, simple firms 
and larger boards are value enhancing for large, complex firms. ${ }^{6}$

Two issues are investigated here. The first is the extent to which firm characteristics, including the extent of individual and institutional blockholdings, influenced board size. The second, and more pertinent issue, is whether board size affected firm value. There are two principal channels through which board size influenced bank value. Larger boards may have been subject to the shirking and coordination problems. It is well known, for example, that boards regularly failed to conduct business for lack of a quorum, which points toward shirking (Gras 1937). One solution was smaller boards, but many banks simply opted to reduce the number needed for a quorum. For the loan-club bank, board size had further salience because larger boards meant more men expecting to be compensated for their time with loans. The larger the board, ceteris paribus, the larger the share of a bank's resources tied up in meeting the board's rather the other shareholders' demands. Larger boards then possibly reduced firm value, controlling for firm size, complexity and other relevant features.

\section{Data and methodology}

\section{$\underline{3.1 \text { Sample }}$}

The population studied here includes Massachusetts banks operating between 1858 and 1862 (see Data Appendix for the details), and the sample is an unbalanced panel of 206 bank-years (approximately four years for 50 banks) drawn from a larger population of 441 bank-years. Massachusetts' bank commissioners conducted biennial on-site inspections for each bank in the state and published detailed reports on their findings. Between 1858 and 1862 their annual reports provide a consistent series of balance sheets, as well as information on the number of shares held by the largest

${ }^{6}$ Adams, Hermalin and Weisbach's (2010) parsimonious model shows that the Coles et al (2008) result holds under certain, fairly general conditions. 
shareholder, shares held by the directors, loans to directors, overdue loans, and loans in default and unlikely to be repaid, among other items. Between 1860 and 1862 the annual reports provided additional information on the number of directors, the number of shares owned by directors, the number of shareholders attending, as well as the number of shares voted at the most recent shareholders' meeting. Some of the variables found in the later reports but not reported in the earlier reports, such as the number of directors and semi-annual dividends, were located in other sources (see Data Appendix).

Information on institutional shareholdings were taken from four annual reports of Massachusetts insurance commissioners. These reports provided detailed information on shares held in each bank at the end of each year, as well as the market price of each bank's shares at the time of the insurance company's reports. The insurance reports are invaluable sources because they provide information on the share prices of banks outside Boston, which are otherwise rarely observed. When the insurance commissioners' reports failed to report a share price for a Boston bank, it was determined from sources discussed in the Data Appendix. Three-quarters (177 of 235) of the dropped observations are dropped because no current market share price was found. Another 30 observations were dropped because the number of shares held by the largest shareholder was the same as the number of shares held by the largest insurance company shareholder. Because, in these instances, it was likely that the largest shareholder was the largest shareholding insurance company rather than an individual, the observations are dropped. The inclusion of these observations would confound estimates of individual and institutional blockholding.

\section{$\underline{3.2 \text { Endogenous variables }}$}

The principal endogenous variable of interest is firm value, measured by Tobin's Q, which is 
defined as:

$$
\mathrm{Q}=\text { (book value assets - book value capital + market value capital)/ (book value assets) }
$$

This is an approximation of Q, but it is highly correlated with actual Q. ${ }^{7}$ Chung and Pruitt's (1994) proxy, on which this definition is based, is highly correlated with more sophisticated calculations, and is the proxy most often used in the literature (Demsetz and Villalonga 2001; Coles et al 2008; RuizMallorquí and Santana-Martin 2011). Q greater than one implies that the market value exceeds the replacement (book) value of the firm, which implies that the market values some unmeasured asset, such as goodwill, knowledge or human capital, proprietary technology or other intangible assets that are likely to generate future economic profits. Q less than one, then, points to a firm in decline or one for which value might be enhanced through changes in policies or management or both.

A second variable of interest is board size, specifically the effects of board size on firm value. As discussed previously, modern studies identify board size to be a powerful predictor of firm value. But endogeneity is an issue. If shareholders are free to adjust board size in response to deviations from maximum firm value, standard empirical designs that regress firm value on board size will not be informative. Logic says that, after including suitable control variables in a regression, no observable relation between board size and firm performance will emerge if shareholders are free to adjust board size in response to deviations from maximum firm value. The problem, of course, is that endogeneity will bias the board-size coefficient toward zero so that a (near) zero coefficient may or may not be evidence of value-maximizing behavior.

The interesting case occurs if (when) boards of nonoptimal size persist, due perhaps to the costs of revising bylaws or other regulations concerning the number of directors. In Massachusetts the

${ }^{7}$ Tobin (1969) originally defined Q as the ratio of the market value to replacement cost (book value) of the firm or its physical capital. 
earliest corporate charters mandated a specific number of bank directors for each bank, but later revisions to the state's banking laws allowed banks to choose any number between 5 and 13 directors. Moreover, the number of directors could be changed from year to year. There is some annual variation in the observed number of directors, but that variation appears to be driven more by short-term exigencies - death or illness, or a director being removed for failure to attend meetings - than by efforts to influence firm value through changes in board size.

Governance within nineteenth-century banks operated across several other margins as well. Freeman, Pearson and Taylor (2012), for example, note that firms could manipulate the attractiveness of individual and institutional blockholdings through various choices. They contend that bank founders might alter the balance between loan club and commercial banking through its choice of location, size and the initial par value of the shares. Locating in Boston, for example, might provide access to a larger capital market, but it might also bring in dividend-preferring investors. Larger banks, whether measured by assets or initial capitalization, would typically attract more investors and, perhaps, a larger fraction of dividend-preferring investors. Finally, they argue that larger par values signaled an intent to attract a certain type of shareholder. Smaller par values attracted "a very inferior constituency" and one more interested in speculating in shares than in the solidity and permanency of the institution (Freeman, Pearson and Taylor 2012, 68). Location and par values were not easily altered, but they were choices made in an effort to influence the firm's type and its value.

Several empirical strategies present themselves as possible solutions to the endogeneity problem. In the case of board size, fixed effects techniques that exploit variation in board size seem reasonable, but fixed effects estimation does not have much statistical power when time-series variations are small compared to cross-sectional differences. The common solution to the endogeneity and simultaneity problems is to estimate simultaneous equations, either two-stage instrumental variables 
(2SLS-IV) regressions when appropriate instruments are available or three-stage least squares (3SLS) when one or more endogenous regressands appear as regressors in a system of simultaneous equations. Because no empirical approach is above criticism, it is reasonable to offer alternative tests to investigate potential correlations, if not causal factors.

The central conclusions drawn from the data are derived from the following simultaneous equations system estimated by three-stage least squares (3SLS):

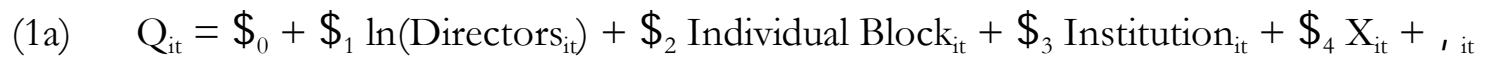

(1b) $\quad \ln \left(\right.$ Directors $\left._{\mathrm{it}}\right)={ }_{0}+{ }_{0}{ }_{1} \mathrm{Q}_{\mathrm{it}}+{ }{ }_{2}$ Individual Block $\mathrm{it}+{ }{ }_{3}$ Institution $_{\mathrm{it}}+{ }_{4} \mathrm{~W}_{\mathrm{it}}+<$

(1c) Individual Block $\mathrm{it}_{\mathrm{it}}=\left(_{0}+\left(_{1} \mathrm{Z}_{\mathrm{it}}+\mathrm{e}_{\mathrm{it}}\right.\right.$

(1d) $\quad$ Institution $_{\text {it }}=6_{0}+6_{1} \mathrm{Y}_{\mathrm{it}}+\mathrm{O}_{\mathrm{it}}$

For comparative purposes, I also report OLS, median and bank-level fixed-effects results for the firm value $(\mathrm{Q})$ equation (1a), as well.

\section{$\underline{3.3 \text { Control variables }}$}

The literature on blockholding, board size and governance provides guidance on which variables to include in a regression to control for confounding effects. Q, for example, is found to be positively associated with firm size, measured as the natural logarithm of total assets. A literature dating to Jensen (1986) also finds that firm value is associated with free cash flow. Firms that hold cash in excess of that needed to fund currently profitable projects have lower Q, most likely because firm managers or others can direct these resources to serve their own purposes rather than enhance shareholder value (Vogt and $\mathrm{Vu}$ 2000). Dividends, too, limit insider expropriation (Faccio, Lang and Young 2001). Two 
variables are included in the regression to capture the free cash flow effect - the last dividend payment as a percentage of par value of shares and retained earnings to capital. Both variables are subject to control by the board and are not, strictly speaking, exogenous, but the data do not offer control variables that allow for endogenizing dividends or retained earnings. To the extent these variables are endogenous, regression coefficients will be biased toward zero and the likely effect is under-estimated.

Empirical studies of the connection between board size (or structure) and firm value control for firm complexity, size, and age. Firm size is included in the regressions as the natural logarithm of total assets. Age is measured as a quadratic in years since establishment. Cubic and higher order specifications did not improve the fit. Firm complexity is measured in the central results as the loan-toasset ratio. Loans are opaque, idiosyncratic assets relative to alternative assets such as government bonds and the more opaque or idiosyncratic the loan portfolio, the greater the demands placed on board decision making. ${ }^{8}$ Coles et al (2008) find that Q is higher for complex firms with larger boards, and the loan-asset ratio is included as a measure of bank complexity.

Table 1 provides the summary statistics for the endogenous and exogenous variables. Mean Q is 1.021, so that the typical bank was valued at about 2 percent more than the market's estimate of the cost to reproduce the book value of its assets. Given that banks exist to overcome information asymmetries and specialize in lending on opaque assets, nineteenth-century markets did not place a large premium on any proprietary information.

${ }^{8}$ As a robustness check, I also include a measure of the banks' involvement in the exchange market. Nineteenth-century banks loaned on either locally payable promissory notes or bills of exchange payable at some distant location. Exchange markets differed from note markets in risk and liquidity. Bills were secured by goods in transit, which made them more secure than notes, but they were payable at a distant location, which meant that a bank needed a reliable agent to collect and remit funds. Bills were also more liquid than notes; there was an active secondary market for bills, especially in larger commercial cities. Banks with more extensive bill operations may have relied more on directors' judgment. Results are not reported, but they are consistent with results in Tables 3 and 4. They are available from the author. 
Table 1 also reveals basic information about early bank governance structures and blockholdings. The average board of directors had just less than eight members. Massachusetts law allowed any number of directors between 5 and 13. Eight banks had the minimum; none had 13, though a handful had 12 directors. The mean largest individual blockholder held $7.4 \%$ of a bank's shares and $56.3 \%$ of banks had a blockholder who held at least $5 \%$ of their shares. The mean largest institutional investor held $2.4 \%$ of its shares. Nearly $11 \%$ of banks had an institutional investor that held $5 \%$ of their shares. Directors, too, were invested in the banks they managed. All directors combined held, on average, $6.9 \%$ of a bank's shares; and $53.3 \%$ of banks were managed by boards that together owned at least a $5 \%$ stake.

The average bank in the sample was 24 years old, controlled more than $\$ 807,000$ in assets, paid a 3.5\% semi-annual dividend, kept a retained earnings-to-asset ratio of about 10\%, slightly less than 4\% of its loans were non-performing (past due but not yet considered bad), and 24\% were in Boston. Dropping observations without observable share prices has a small impact on the mean characteristics of the sample. The mean age for the population of Massachusetts banks was 23 years; $23.2 \%$ were in Boston; they paid an average semi-annual dividend of 3.6\%, had 8.02 directors and controlled, on average, $\$ 719,200$ in assets. Thus, the banks in the final sample are larger than the population mean, but they are otherwise representative of Massachusetts's banks.

\section{Results}

\section{$\underline{4.1 \text { Univariate tests }}$}

Table 2 reports $Q$ values for firms with characteristic values above and below the median value of the stated characteristic. That is, the first row reports the $\mathrm{Q}$ value for firms with above and below the median number of directors (8). The last column provides a simple t-test of differences in the mean 
value of $\mathrm{Q}$ for firms below and above the median number of directors. Thus, firms with fewer than 8 directors have a Q ratio of 1.017, while firms with more than 8 directors have an average Q ratio of 1.034. The difference is statistically significant at the $3 \%$ level.

Tests of differences between most of the relevant variables are statistically significant. Most studies find that larger firms have higher $Q$ ratios than small firms; that feature holds for Massachusetts's banks. Banks with a large, unaffiliated institutional investor have higher Q ratios on average. Having a large individual shareholder holding more than the median fraction of shares is not associated with a higher $\mathrm{Q}$ ratio, however. This result may signify that large shareholders did not effectively monitor and discipline; or it may be indicative of the tension between investor-shareholders and consumer-shareholders discussed above. Banks that paid higher dividends had notably higher Q ratios, suggesting that at least some shareholders viewed bank shares as dividend-generating investments rather than loan clubs. Of course, even loan club members valued dividends for a given savings on loans. Finally, managers' and directors' business decisions also influenced bank value. Firm value was higher for banks with above-median levels of retained earnings relative to capital. Although free cash concerned some investors because it provided the wherewithal for self-interested managers to consume perquisites, retained earnings also provided banks with the wherewithal to pay dividends in future periods and insulated management from shareholder discontent following a temporary period of poor earnings. One source of poor earnings were nonperforming loans and Q ratios were higher for banks with below-median proportions of bad loans.

\section{$\underline{4.2 \text { Multivariate tests }}$}

Univariate tests provide some insights into differences in $\mathrm{Q}$ values for banks with different characteristics, but they fail to account for endogeneity, simultaneity, or other confounding factors. 
Table 3 reports the results on regressions explaining bank value using four different approaches. Column 1 reports coefficient estimates from an ordinary least squares (OLS) regression of observable bank characteristics on bank value. All else constant, Q increased in bank size, with the presence of an individual investor holding at least 5 percent of the bank's shares, when directors as a group held at least 5 percent of a bank's shares, and with higher retained earnings-to-capital ratios. Firm value declined in board size, in the presence of a large unaffiliated investor, in dividend payments, and in the proportion of nonperforming loans. Median and bank-level fixed-effects regressions generate coefficient estimates of similar sign and magnitude.

The problem with OLS, median and fixed-effects estimates, of course, is that several of the independent variables are endogenous so that OLS and median regressions coefficients on the potentially endogenous variables will be biased toward zero. Fixed-effects models do not have much statistical power because, for example, board size and dividends do not exhibit much temporal variation and fixed-effects estimates rely on within-firm variation to identify a causal effect (Coles, Daniel and Naveen 2008; Larmou and Vafeas 2010). Board size and dividends varied more across firms at a moment in time than within firms across time. The fixed-effect estimates ignore that cross-sectional variation.

The standard approach to endogeneity in the literature is to estimate a system of equations through three-stage least squares (3SLS) in which each potentially important explanatory variable is endogenized. I follow Coles, Daniel and Naveen (2008), Linck, Netter and Yang (2008), Jiao (2010) and Larmou and Vafeas (2010) and endogenize board size because estimates that regress firm value on board size will not be informative if shareholders are free to adjust boards to maximize bank value. Interesting cases occur when boards are of potentially non-optimal size because some friction or transaction cost impedes timely adjustments. Over the longer horizon, it may take time for shareholders 
to approve changes in board size if doing so requires an amendment to the bylaws; over a shorter horizon, it may take time to identify, appoint and seat a replacement for a seat vacated due to death or resignation. In these instances it is possible that board size may be non-optimal given other bank characteristics.

Studies of modern corporations find that board size is related to Q, firm size, complexity, age and ownership structure (Linck, Netter and Yang 2008; Pathan and Skully 2010). Firm size is measured as the natural logarithm of total assets. Firm complexity is measured as the loan-asset ratio. Compared to government bonds, the principal alternative investment in a bank portfolio, bank loans are idiosyncratic, informationally opaque to outsiders, and difficult to price to market. Studies have found that firm value increases in board size for more complex firms, so it is expected that larger boards will enhance the value of more complex banks. Bank age enters as a quadratic in years since the original corporate charter was secured. Two variables - the presence of a 5\% individual blockholder and the presence of a 5\% institutional blockholder - capture ownership structure. ${ }^{9}$ The board size equation is well specified (see Appendix Table A1): most of the coefficients have the expected signs and are individually significant; and the chi-squared statistic (36.4) for joint significance has a p-value less than 0.001 .

Ownership structures, too, are endogenous to bank characteristics. They are endogenized and separate equations are included in the 3SLS system for the presence of an individual blockholder with at least a $5 \%$ stake and for the presence of an institutional blockholder with at least a 5\% stake. Freeman, Pearson and Taylor (2012) argue that nineteenth-century blockholdings were associated with firm location (city or town), firm size, and the initial par value of shares. The equation specification

${ }^{9}$ It is standard practice in the empirical literature is to impose the $5 \%$ demarcation on blockholdings (Borokhovich 2006). This standard is relaxed and alternative specifications as robustness checks. The results are discussed in Section 5 below. 
follow from Freeman, Pearson and Taylor's finding and are well specified: the explanatory variables take on the expected signs, and are individually and jointly significant (see Appendix Table A1).

The last column of Table 3 presents the 3SLS estimates of the determinants of bank value (Tobin's Q), several features of which are notable. First, the 3SLS estimates tend to be larger in absolute value than the OLS, median or fixed-effects estimates, which is consistent with the concern that OLS estimates will be biased toward zero in the presence of endogenous regressors. Second, the signs and the magnitudes of the estimates are generally consistent with studies of modern firms, which suggests a degree of timelessness to some issues of corporate governance. Firm value, for instance, increased in firm size. A one standard deviation increase in the log of firm size (0.81) is associated with a 2.2 standard deviation increase in Q. Bank value decreased in board size; increasing the average board size by two-thirds of a member (= one standard deviation in predicted $\ln ($ Directors) $)$ decreases Q by about 27 percent. The magnitude of the estimated effect suggests that deviations from optimal board size had substantial market effects.

The central concern here is the association between blockholdings and firm value, and the 3SLS results are broadly more consistent with the shareholder-customer than the shareholder-investor hypothesis. The coefficient on the $5 \%$ Individual blockholder variable is 0.336 , but the coefficient cannot be interpreted to mean that Q is 34\% higher for banks with an individual 5\% blockholder, all else constant. Rather, the regression estimates a coefficient for the predicted probability of having an individual 5\% blockholder, not the presence of such a blockholder. Thus, bank value is $34 \%$ higher for a bank predicted to have a 5\% blockholder with certainty than for a bank predicted not to bave a $5 \%$ blockholder with certainty. Given the implausibly large effect associated from a change in predicted probability from zero to one, Becker, Cronqvist and Fahlenbrach (2011) suggest multiplying the coefficient by the interquartile range of the distribution of predicted probabilities to obtain a more 
realistic effect. A bank moving from the $25^{\text {th }}$ to the $75^{\text {th }}$ percentile of predicted probabilities of having a 5\% blockholder would have experienced an increase in Q of $0.097(=0.336 \times 0.39)$, which is about twice the interquartile difference in $\mathrm{Q}$ or about equal to the $90^{\text {th }}-10^{\text {th }}$ percentile difference in Q. Large blockholders had a large positive predicted influence on bank value.

Among the potential explanations for the 5\% blockholder effect are the Shleifer and Vishny (1986) contention that large block shareholders have incentives to monitor and discipline bankers, which increases bank value. An alternative blockholder-as-customer explanation holds that the blockholder effect works through the blockholder's ability to ward off attempts by investors with a preference for dividends to change policy away from preferential credit access for owner-customers to a more profit-oriented policy. To the extent that blockholders can deflect shareholder-investor demands for dividends, shareholder-customers will bid up the price of shares and increase Q. Absent other information, it would be difficult to unravel the investor and customer hypotheses. But two other pieces of evidence point toward the blockholder-customer interpretation. First, when the board of directors are predicted to jointly control at least $5 \%$ of the shares, Q increases by $6.3 \%$ or about 1.4 standard deviations in Q. Because they were compensated mostly through the preferential access to credit afforded board members, the effect of $5 \%$ board ownership is consistent with boards supporting the shareholder-customer model of banking.

Additional evidence in support of the shareholder-customer model is seen in the negative effect of dividend-preferring, nonaffiliated institutional blockholding on Q. Alhough statistically insignificant, the coefficient on $5 \%$ insurance shareholding works in the opposite direction of the blockholder effect. Because the 5\% insurance-owner coefficient also captures the predicted probability of such ownership, it is interpreted like the 5\% individual blockholder coefficient; thus, multiplying the coefficient by the interquartile range of predicted probabilities of institutional ownership implies a modest $0.6 \%$ decline 
in Q. Further, the coefficient on the last dividend payment is small and insignificant. A one standard deviation increase in dividend yield implies an equally modest $0.6 \%$ decline in $\mathrm{Q}$. This last effect is consistent with the hypothesis that bank shareholders were more interested in low-cost credit than dividend yield.

Although the estimates cannot be interpreted as causal effects, bank portfolio choices are also associated with bank value. Banks with boards with a poor track record in loan decisions had lower market values. A one standard deviation increase in the ratio of nonperforming loans to loans is associated with a 1.3\% decline in Q. Free cash flow, on the other hand, is associated with higher bank values. A standard deviation increase in the retained earnings-to-asset ratio is associated with a $1 \%$ increase in Q. Jensen (1986) argues that free cash flow provided self-serving managers with opportunities for perquisite consumption at the expense of shareholders. Nineteenth-century investors did not negatively react to free cash holdings at bank, probably because retained earnings provided a buffer against below average earnings in the short term, which allowed banks to meet the dividend expectations of unaffiliated investors.

\section{Robustness checks}

\section{$\underline{5.1 \text { Alternative threshold and linear blockholder specifications }}$}

Because the monitoring power and influence of individual and institutional investors may be subject to threshold effects, it is important to investigate alternative linear and nonlinear measures of shareholdings (Chen, Harford and Li 2007). Many studies find a threshold effect around 5\% blockholding and estimate regressions, like those reported above, that use the 5\% blockholding cutoff. Imposing the 5\% threshold on historical data may not, however, be justified if the threshold proportion of ownership at which blockholders influenced corporate policy was systematically different. To 
investigate the possibility of different historical thresholds, the system of equations was re-estimated using either $3 \%$ or $7 \%$ blockholder thresholds, as well as a specification that allows the blockholder shares to enter linearly.

Table 4 provides the results of these tests. Using either a 3\% or 7\% threshold does not alter the basic interpretations discussed in Section 4. The certain predicted presence of a 3\% or 7\% individual blockholder increases bank Q values. Large predicted institutional 3\% or 7\% blockholdings and actual dividends decreased Q. It is important to recall that the estimated coefficients reflect the predicted effect of a change from zero predicted probability to a certainty of a the relevant blockholding. Multiplying the coefficient by the interquartile (or other) range generates large, but plausible effects. Both of these specifications are consistent with the shareholder-customer model of nineteenth-century bank shareholding.

The third column of Table 4 reports the estimated effects when blockholdings enter the 3SLS system specifications linearly. The predicted effect of either a one standard deviation increase in the $\log$ number of directors $(-20.0 \%)$ or an interquartile increase in the log number of directors $(-20.0 \%)$ are substantial and suggest powerful negative consequences of non-optimal board size. The predicted effects of individual and institutional blockholders using the linear specification are similar to those generated using the 5\% thresholds. The estimated change in Q resulting from a one standard deviation change in the predicted share of the largest individual blockholding $\left({ }^{*} \mathrm{Q} /{ }^{*}\right.$ Individual $\left.=6.6 \%\right)$, in the predicted fraction of shares held by largest institutional blockholding $\left({ }^{*} \mathrm{Q} /{ }^{*}\right.$ Institution $=0.3 \%$, and in the actual combined director blockholding $\left({ }^{*} \mathrm{Q} /{ }^{*}\right.$ Director $\left.=3.8 \%\right)$ are consistent with the shareholder-customer hypothesis. Multiplying the coefficients by the interquartile range of predicted individual blockholding (11.8\%) and institutional blockholding (0.8\%) are also large but plausible in magnitude. The negative, though small coefficient on the last dividend suggests that directors satisfied 
investor demands while maintaining the shareholder-customer preference for loans at below-market rates.

\section{$\underline{5.2 \text { Endogenizing director preferences }}$}

To this point the analysis assumes that directors have similar tastes for on-the-job and takehome income, which may not be the case (Demsetz 1983). Different types of directors may have different tastes. It is well known, for example, that some men took on the task of directorship because it gave them preferential access to bank credit. One concern is that director-borrowers might not be as disciplined as non-borrowing directors. That is, in order to insure their own access, some directors might approve low expected return (bad) loans from fellow directors in a "I vote for yours, if you vote for mine" agreement. Merchants seeking this kind of preferential access may have gravitated toward share ownership and directorship in certain banks. In effect, they were willing to trade lower capitalgains or dividend returns on their investments for greater access to credit. Sharing profits provides some incentives to voluntarily limit self-dealing; it does not eliminate such incentives.

Imagine then two banks; one chooses a high-monitoring regime in which shareholders, through various means, restrict directors' access to credit; and, a second bank that chooses a low-monitoring regime in which directors are reasonably free to self-deal. The former bank will attract shareholder/directors whose utility is increased more by increases in capital gains or dividend income than through preferential access to loans. Directors at this type of bank do not allow their fellows to self-deal and lend large amounts to themselves. The low-monitoring regime bank, on the other hand, attracts shareholder/directors whose utility is increased more by preferential access to loans than by increases in capital gains or dividend income. A greater proportion of the loans made at the lowmonitoring regime bank are, therefore, made to directors and other insiders. If high-monitoring regime 
banks are those with large blockholders, we should observe a negative relationship between the share of a bank's loans made to directors and the extent of large blockholding. Even those shareholders with a preference for low-interest loans place a lower value on banks with heavily self-dealing directors than banks without. Moreover, given the preference of shareholder/directors for take-home income in the high-monitoring regime banks, Q should be inversely related to either the absolute value or share of a bank's loans going to directors.

Massachusetts' bank commissioners collected information on loans to directors as principals. It is well known that the official bank statements understate the true extent of director self-dealing because board members could and did approve loans to family members, business partners and others with whom they had outside business relationships (Lamoreaux 1994). The reports, though less than fully informative concerning insider lending, may have provided information that shareholders and others responded to. To the extent that the official bank statements under-report insider lending, any estimates of its effects are biased downward.

To investigate the possibility that director self-lending influenced bank value, a fifth equation:

(1e) $\quad(\text { Director loan } \%)_{\text {it }}=B_{0}+B_{1}$ Individual Block $_{\text {it }}+B_{2}$ Institution $_{\text {it }}+B_{3} \ln \left(\right.$ Directors $\left._{\mathrm{it}}\right)+\mathrm{B}_{4} \mathrm{~V}_{\mathrm{it}}$ $+\mathrm{L}_{\mathrm{it}}$

is added the 3SLS system described in Section 3. The results of two alternative specifications of bank value $(\mathrm{Q})$ and director loan share regressions are reported in Table $5 .{ }^{10}$ Coefficients reported in the first column make use of the 206 observations included in the previous regressions. Bank Q increases

${ }^{10}$ The equations for $\ln$ (Directors), Individual Block, and Institutional shareholding are similar to those reported in Table A1 and are not reported here. 
in bank size, free cash and the predicted probability of an individual blockholder with at least 5\% of the bank's shares; it declines in non-performing loans, the last dividend, and predicted board size. The principal difference between this specification and the baseline result in Column 4 of Table 3 is that effect of the predicted probability of an institutional blockholder switches sign and becomes statistically significant. The estimated coefficient suggests that an interquartile increase in the predicted probability of an institutional investor holding at least $5 \%$ of a bank's shares will increase $Q$ by about $0.3 \%$, which is consistent with the institutional investors having a modest disciplinary effect on board choices and bank policy.

Coefficients reported in the second column make use of a smaller number of observations using only those reports in which the bank commissioners stated the number of shares voted at the last general shareholders' meetings. Including this variable halves the number of observations, but provides some information about how shareholders responded to director self-dealing. If shareholders viewed such self-dealing negatively, the share of loans taken up by directors should be negatively related to shareholder activism. This regression is better specified (significantly larger $\mathrm{P}^{2}$ statistic) than the larger sample regression in Column 1, but the coefficients are comparable. Two notable effects of shareholder activism are: when more shares are voted, directors take up a smaller fraction of a bank's loans; and, firm value declined markedly in the predicted share of a bank's loans taken up by a bank's directors. An interquartile increase in the predicted fraction of loans to directors decreases Q by $19.3 \%$. This is a powerful effect, though it reflects in part the substantial variation across banks. The mean predicted fraction of loans taken is just $1.3 \%$ whereas the predicted median is $17.7 \%$, with an interquartile range of $29.1 \%$, which is more than three times the interquartile range in the raw data. Multiplying the estimated coefficient by the actual interquartile range in the fraction of loans taken by directors still implies a decrease in firm value of a nontrivial $6.9 \%$. 
Although the available measure underestimates its extent, the market responded negatively to increased director self-dealing. Based on published reports alone, shareholders could not know the true extent of insider lending. Three responses are evident in the data, however. Less self-dealing occurred at banks with large institutional shareholders and at banks with more active shareholders. And, the market bid down share prices at banks with more director self-dealing. This last result is consistent with the shareholder-customer hypothesis because when directors took up a large fraction of a bank's loans, there were less loanable funds available for other shareholders and outsiders. Shareholdercustomers paid less in expectation of smaller or fewer loans, and shareholder-investors anticipated lower dividend yields. Both would bid down the price of bank shares.

\section{Conclusions}

Organized markets for corporate shares in the mid-nineteenth century were thin, some firm's shares traded only rarely, shares of others were not even listed on organized exchanges, and timely information about a company's performance was often difficult to acquire. These four features of the market for early American corporate shares justifiably lead to questions concerning the ability of shareholders and other market participants to monitor and discipline firms and their managers. The threat of activist shareholders or corporate raiders ousting under-performing management seems an unlikely disciplinary mechanism. Further compounding the difficulties of outside discipline, some states limited the number of shares an individual or institutional shareholder could legally hold. ${ }^{11}$ Other states, Massachusetts included, limited the power of large shareholders by placing limits on the number of votes they could cast at shareholder meetings. The potential for managerial or majority shareholder self-

\footnotetext{
11 The charters of several of Connecticut's earliest banks capped the number of shares any individual or partnership could own. It was possible to work around the caps by splitting shares among family members, but this increased the cost of exercising corporate control.
} 
serving in such an environment appear enormous.

Despite the potential for corporate governance to break down in the era, there is little evidence that it did. While the ability of shareholders to control corporate policy was imperfect, Hilt (2008) and Freeman, Pearson and Taylor (2012), among others, show that shareholders could and did discipline managers and influence corporate policies. This study adds to the literature. Evidence from one important mid-nineteenth century banking market shows that the presence of individual and institutional blockholders influenced firm value. Because people conceived of the corporation differently then and because corporations solved a different set of problems in the nineteenth century, the channels of influence work in ways more consistent with the corporation of its own time than of ours. Any assessment of corporate performance must come to terms with the connection between the corporation as an historical entity, but modern conceptions of the corporation are not without merit in studying the institution.

\section{Data Appendix}

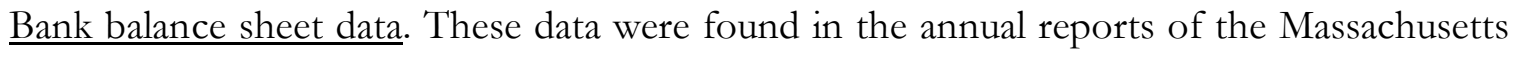
bank commissioners. The same basic balance sheet data was published in each year between 1858 and 1862. Each annual reports included information on the principal assets, namely, loans, specie, real estate, and amounts due from other banks. The principal liabilities were banknote circulation, deposits, amounts due to other banks, capital and retained earnings.

Blockholdings. Large block individual holdings were reported in the annual reports. In the ancillary information provided with the balance sheets was a statement of the number of shares held by the largest shareholder, whether individual or corporation. Large block institutional share holdings 
were found in the annual reports of Massachusetts insurance commissioners. The insurance reports included each insurance company's holdings of individual stocks in bonds in their fourth, sixth, seventh and eighth annual reports. This information was used to construct institutional holdings. When the number of shares held by the largest shareholder described in the bank commissioners' reports was the same the number of shares held by the largest insurance company shareholder, the observation was dropped because it is likely that the largest shareholder was the insurance company and not an individual.

Number of directors. With the exception of 1858 , the number of directors was included in the ancillary information attached to the balance sheet. The number of directors in 1858 was taken from the Massachusetts Register, which listed the names of bank board members in that year.

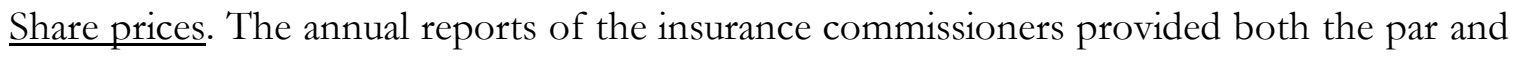
market price of shares in those years. The sixth annual report noted that the market price for all shares was on one day in October. No mention of the source of the market price is provided in the other three years, so it is unclear whether it a recent price or an average price over some interval. In the years in which no insurance report was available or no market price was provided, prices for Boston banks are available in Martin's Seventy-Three Years' History.

\section{Data Sources}

Adams, Sampson \& Co. 1858. The Massachusetts Register, Containing a Record of the Government and Institutions of the State. Boston: Damrell \& Moore, Printers.

Martin, Joseph G. 1871. Seventy-Three Years' History of the Boston Stock Market. Boston: published by the author. 
Massachusetts. General Court. 1858. Annual Report of the Bank Commissioners. Boston: William White, State Printer.

Massachusetts. General Court. 1859. Annual Report of the Bank Commissioners. Public Doc. No. 6. Boston: William White, State Printer.

Massachusetts. General Court. 1859. Fourth Annual Report of the Insurance Commissioners of the Commonwealth of Massachusetts. Public Document No. 8. Boston: William White, State Printer.

Massachusetts. General Court. Annual Report of the Bank Commissioners. Public Doc. No. 10. Boston: William White, State Printer.

Massachusetts. General Court. 1861. Annual Report of the Bank Commissioners. Public Doc. No. 8. Boston: William White, State Printer.

Massachusetts. General Court. 1861. Abstracts of Returns from the Banks and from the Institutions for Savings in Massachusetts. Public Document No. 9. Boston: William White, State Printer.

Massachusetts. General Court. 1861. Sixth Annual Report of the Insurance Commissioners of the Commonwealth of Massachusetts. Public Document No. 12. Boston: William White, State Printer.

Massachusetts. General Court. 1862. Annual Report of the Bank Commissioners. Public Document No. 8. Boston: Wright \& Potter, State Printers.

Massachusetts. General Court. 1862. Seventh Annual Report of the Insurance Commissioners of the Commonwealth of Massachusetts. Boston: Wright \& Potter, State Printers.

Massachusetts General Court. 1863. Eighth Annual Report of the Insurance Commissioners of the Commonwealth of Massachusetts. Public Document No. 10. Boston: Wright \& Potter, State Printers.

9. References

Adams, Renée B., Benjamin E. Hermalin, and Michael S. Weisbach. 2010. "The Role of Boards of 
Directors in Corporate Governance: A Conceptual Framework and Survey." Journal of Economic Literature 48.1, 58-107.

Bebchuk, Lucian A. and Alma Cohen. 2005. "The Costs of Entrenched Boards." Journal of Financial Economics 78, 409-433.

Becker, Bo, Henrik Cronqvist, and Rüdiger Fahlenbrach. 2011. "Estimating the Effects of Large Shareholders using a Geographic Instrument.” Journal of Financial and Quantitative Analysis 46.4, 907-942.

Bethel, Jennifer E., Julia Porter Liebeskind, and Tim Opler. 1998. "Block Share Purchases and Corporate Performance." Journal of Finance 53.2, 605-634.

Bodenhorn, Howard. 2003. State Banking in Early America: A New Economic History. New York: Oxford University Press.

Bodenhorn, Howard. 2012. "Voting Rights, Share Concentration and Leverage at Nineteenth-Century US Banks.” NBER working paper.

Borokhovich, Kenneth A., Kelly Brunarski, Yvette S. Harman, and Robert Parrino. 2006. "Variation in the Monitoring Incentives of Outside Stockholder.” Journal of Law \& Economics 49.2, 651-680.

Brickley, James, Ronald Lease, and Clifford Smith. 1986. “Ownership Structure and the Voting on Antitakeover Amendments.” Journal of Financial Economics 20, 267-291.

Chen, Xia, Jarrad Harford, and Kai Li. 2007. "Monitoring: Which Institutions Matter?” Journal of Financial Economics 86.2, 279-305.

Chung, Kee H. And Stephen W. Pruitt. 1994. “A Simple Approximation of Tobin’s q.” Financial Management 23.3, 70-74.

Coles, Jeffrey L., Naveen D. Daniel and Lalitha Naveen. 2008. “Boards: Does One Size Fit All?” Journal of Financial Economics 87.2, 329-356. 
Demsetz, Harold. 1983. "The Structure of Ownership and the Theory of the Firm.” Journal of law and Economics 26.2, 375-390.

Demsetz, Harold and Kenneth Lehn. 1985. "The Structure of Corporate Ownership: Causes and Consequences." Journal of Political Economy 93.6, 1155-1177.

Demsetz, Harold and Villalonga. 2001.

Duru, Augustine, Dechen Wang, and Yijiang Zhao. 2013. "Staggered Boards, Corporate Opacity and Firm Value." Journal of Banking and Finance 37, 341-360.

Elyasiani, Elyas and Jia Jingyi. 2010. "Distribution of Institutional Ownership and Corporate Firm Performance." Journal of Banking \& Finance 34, 606-620.

Faccio, Mara, Larry H. P. Lang, and Leslie Young. 2001. "Dividends and Expropriation.” American Economic Review 91.1, 54-78.

Freeman, Mark, Robin Pearson, and James Taylor. 2012. Shareholder Democracies? Corporate Governance in Britain \& Ireland before 1850. Chicago: University of Chicago Press.

Gillan, Stuart L. And Laura T. Starks. 2000. "Corporate Governance Proposals and Shareholder Activism: The Role of Institutional Investors.” Journal of Financial Economics 57.2, 275-305.

Gordon, Myron J. 1959. “Dividends, Earnings, and Stock Prices.” Review of Economics and Statistics 41.2, 99-105.

Gras, N. S. B. 1937. The Massachusetts First National Bank of Boston, 1784-1934. Cambridge: Harvard University Press.

Guinnane, Timothy W., Ron Harris, Naomi R. Lamoreaux, and Jean-Laurent Rosenthal. 2007. "Putting the Corporation in its Place." Enterprise \& Society 8.3, 687-729.

Harris, Ron. 2009. "Law, Finance, and the First Corporations." In Global Perspectives on the Rule of Law. Edited by James J. Heckman, Robert L. Nelson and Lee Cabatingan. Routledge. 
Hansmann, Henry and Mariana Parglender. 2012. "The Evolution of Shareholder Voting Rights: Separation of Ownership and Consumption.” Yale Law School working paper.

Hilt, Eric. 2008. "When Did Ownership Separate from Control? Corporate Governance in the Early Nineteenth Century." Journal of Economic History 68.3, 645-685.

Jarrell, Gregg A., James A. Brickley and Jeffry M. Netter. 1988. "The Market for Corporate Control: The Empirical Evidence since 1980.” Journal of Economic Perspectives 2.1, 49-68.

Jensen, Michael C. 1986. "Agency Costs of Free Cash Flow, Corporate Finance and Takeovers." American Economic Review 76.2, 323-329.

Jiao, Yawen. 2010. “Stakeholder Welfare and Firm Value.” Journal of Banking \& Finance 34, 2549-2561.

Lamoreaux, Naomi R. 1994. Insider Lending: Banks, Personal Connections, and Economic Development in Industrial New England. New York: Cambridge University Press.

Lamoreaux, Naomi R. 2011. "Scylla or Charybdis? Some Historical Reflections on the Two Basic Problems of Corporate Governance.” Business History Review 83.1, 9-34.

Lamoreaux, Naomi R and Christopher Glaisek. 1991. "Vehicles of Privilege or Mobility? Banks in Providence, Rhode Island during the Age of Jackson.” Business History Review 65.3, 537-557.

Larmou, Sofia and Nikos Vafeas. 2010. "The Relation between Board Size and Firm Performance in Firms with a History of Poor Operating Performance.” Journal of Management Governance 14, 6185.

Linck, James S., Jeffrey M. Netter, and Tina Yang. 2008. “The Determinants of Board Structure." Journal of Financial Economics 87, 308-328.

Massachusetts. General Court. 1812. The Law of the Commonwealth of Massachusetts from February 28, 1807 to February 29, 1812. Vol 1. New Series. Boston: Thomas \& Andrews.

Meissner, Christopher. 2005. "Voting Rules and the Success of Connected Lending in Nineteenth 
Century New England Banks.” Explorations in Economic History 42.4, 509-528.

Musacchio, Aldo. 2009. Experiments in Financial Democracy: Corporate Governance and Financial Development in Brazil, 1882-1950. New York: Cambridge University Press.

Private and Special Statutes of the Commonwealth of Massachusetts. Vol. VI. 1837. Boston: Dutton \& Wentworth, State Printers.

Parglender, Mariana and Henry Hansmann. 2013. "A New View of Shareholder Voting in the Nineteenth Century: Evidence from Brazil, England and France." Business History (forthcoming).

Pathan, Shams and Michael Skully. 2010. "Endogenously Structured Boards of Directors in Banks." Journal of Banking \& Finance 34, 1590-1606.

Ruiz-Mallorqui, Maria Victoria and Domingo J. Santana-Martin. 2011. “Dominant Institutional Owners and Firm Value." Journal of Banking \& Finance 35, 118-129.

Shleifer, Andrei and Robert W. Vishny. 1986. “Large Shareholders and Corporate Control.” Journal of Political Economy 94.3, 461-488.

Sylla, Richard, John J. Wallis and John B. Legler. 1987. "Banks and State Public Finance in the New Republic, 1790-1860." Journal of Economic History 47.2, 391-403.

Tobin, James. 1969. “A General Equilibrium Approach to Monetary Theory.” Journal of Money, Credit, and Banking 1.1, 15-29.

Vogt, Stephen C. And Joseph D. Vu. 2000. "Free Cash Flow and Long-Run Firm Value: Evidence from the Value Line Investment Survey.” Journal of Managerial Issues 12.2, 188-207.

Wainwright, Nicholas B. 1953. History of the Philadelphia National Bank: A Century and a Half of Philadelphia Banking, 1803-1953. Philadelphia: William F. Fell, printer.

Woidtke, Tracie. 2002. “Agents Watching Agents? Evidence from Pension Fund Ownership and Firm 
Value.” Journal of Financial Economics 63.1, 99-131.

Yermack, David. 1996. "Higher Market Valuation of Companies with a Small Board of Directors." Journal of Financial Economics 40, 185-211. 
Table 1

Summary statistics

\begin{tabular}{|c|c|c|}
\hline Variable name & Mean & Std Dev \\
\hline Q & 1.021 & 0.046 \\
\hline Directors & 7.995 & 1.544 \\
\hline$\%$ shares largest shareholder & 0.074 & 0.058 \\
\hline $5 \%$ owner & 0.563 & 0.497 \\
\hline$\%$ shares all insurance companies & 0.056 & 0.056 \\
\hline$\%$ shares largest insurance company & 0.024 & 0.018 \\
\hline $5 \%$ insurance owner & 0.107 & 0.309 \\
\hline$\%$ shares owned by directors & 0.069 & 0.051 \\
\hline $5 \%$ director ownership & 0.533 & 0.500 \\
\hline $\log$ Assets & 13.211 & 0.809 \\
\hline Last dividend (\%) & 0.036 & 0.007 \\
\hline Retained earnings/assets & 0.107 & 0.053 \\
\hline Nonperforming loans/loans & 0.039 & 0.052 \\
\hline Bank age (yrs) & 24.038 & 15.081 \\
\hline Boston & 0.243 & 0.429 \\
\hline
\end{tabular}

$-40-$ 
Table 2

Univariate tests of $Q$ ratio

\begin{tabular}{|c|c|c|c|c|}
\hline Variable & $\begin{array}{l}\text { Median } \\
\text { value }\end{array}$ & $\begin{array}{c}\text { Average } Q \\
\text { below median firms }\end{array}$ & $\begin{array}{c}\text { Average } Q \\
\text { above median firms }\end{array}$ & $\begin{array}{c}\text { t-test } \\
\text { (p-value) }\end{array}$ \\
\hline Directors & 8 & 1.017 & 1.034 & $\begin{array}{c}2.17 \\
(0.030)\end{array}$ \\
\hline $\ln$ (Assets) & 13.00 & 1.009 & 1.045 & $\begin{array}{c}3.95 \\
(>0.001)\end{array}$ \\
\hline $\begin{array}{l}\% \text { shares largest } \\
\text { shareholder }\end{array}$ & 0.055 & 1.021 & 1.022 & $\begin{array}{c}0.19 \\
(0.85)\end{array}$ \\
\hline $\begin{array}{l}\% \text { shares largest } \\
\text { insurance company }\end{array}$ & 0.024 & 1.018 & 1.040 & $\begin{array}{c}2.40 \\
(0.017)\end{array}$ \\
\hline Last dividend (\%) & 3.50 & 1.005 & 1.054 & $\begin{array}{c}4.11 \\
(>0.001)\end{array}$ \\
\hline $\begin{array}{l}\text { Retained earnings / } \\
\text { capital }\end{array}$ & 0.010 & 1.013 & 1.046 & $\begin{array}{c}3.64 \\
(>0.001)\end{array}$ \\
\hline $\begin{array}{l}\text { Nonperforming } \\
\text { loans / loans }\end{array}$ & 0.024 & 1.039 & 1.020 & $\begin{array}{c}2.06 \\
(0.040)\end{array}$ \\
\hline
\end{tabular}


Table 3

Determinants of firm value (Tobin's $Q$ )

\begin{tabular}{lcccc}
\hline & OLS & Median & Fixed-effects & 3SLS \\
\hline log Assets & 0.023 & 0.019 & 0.019 & 0.124 \\
& $(0.004)^{* * *}$ & $(0.004)^{* * *}$ & $(0.022)$ & $(0.034)^{* * *}$ \\
log Directors & -0.027 & -0.006 & -0.013 & -0.428 \\
& $(0.016)^{*}$ & $(0.014)$ & $(0.015)$ & $(0.162)^{* * *}$ \\
5\% Individual & 0.015 & 0.009 & 0.010 & 0.336 \\
Owner & $(0.007)^{* *}$ & $(0.005)^{*}$ & $(0.008)$ & $(0.121)^{* * *}$ \\
5\% Insurance & -0.011 & -0.006 & -0.004 & -0.106 \\
Owner & $(0.010)$ & $(0.008)$ & $(0.006)$ & $(0.098)$ \\
5\% Director & 0.011 & 0.002 & -0.002 & 0.063 \\
Ownership & $(0.008)$ & $(0.007)$ & $(0.010)$ & $(0.023)^{* * *}$ \\
Last Dividend (\%) & -0.011 & 0.021 & 0.028 & -0.008 \\
& $(0.019)$ & $(0.01)^{* *}$ & $(0.012)^{* *}$ & $(0.008)$ \\
Nonperforming & -0.125 & -0.067 & -0.043 & -0.256 \\
loans & $(0.084)$ & $(0.059)$ & $(0.062)$ & $0.121)^{* *}$ \\
Retained earnings & 0.257 & 0.172 & 0.006 & $(0.105)^{*}$ \\
& $(0.074)^{* * *}$ & $(0.063)^{* * *}$ & $(0.090)$ & \\
R-squared & & & & \\
F-statistic & 0.23 & 0.23 & $0.33($ within $)$ & \\
\hline & $7.44 * * *$ & $4.48 * * *$ & & \\
Notsquare & & & & \\
\hline
\end{tabular}

Notes: 206 observations. Dependent variable is Q. ${ }^{* * *}$ implies $\mathrm{p}<0.01$; ${ }^{* *}$ implies $\mathrm{p}<0.05$; and $*$ implies $\mathrm{p}<0.10$.

Robust standard errors clustered on bank in parentheses.

Sources: Authors calculation from data described in Data Appendix 
Table 4

Robustness checks

Determinants of firm value

\begin{tabular}{|c|c|c|c|}
\hline & $3 \%$ owners & $7 \%$ owner & Large owner $\%$ \\
\hline $\log$ Assets & $\begin{array}{c}0.108 \\
(0.017)^{* * *}\end{array}$ & $\begin{array}{c}0.160 \\
(0.081)^{* *}\end{array}$ & $\begin{array}{c}0.143 \\
(0.414)^{* * *}\end{array}$ \\
\hline Log Directors & $\begin{array}{l}-0.007 \\
(0.139)\end{array}$ & $\begin{array}{l}-0.801 \\
(0.448)^{*}\end{array}$ & $\begin{array}{c}-0.420 \\
(0.179)^{* *}\end{array}$ \\
\hline Last dividend & $\begin{array}{l}-0.003 \\
(0.005)\end{array}$ & $\begin{array}{l}-0.004 \\
(0.009)\end{array}$ & $\begin{array}{l}-0.003 \\
(0.009)\end{array}$ \\
\hline $\begin{array}{l}\text { Nonperforming loans / } \\
\text { loans }\end{array}$ & $\begin{array}{l}-0.070 \\
(0.092)\end{array}$ & $\begin{array}{c}-0.339 \\
(0.162)^{* *}\end{array}$ & $\begin{array}{l}-0.069 \\
(0.116)\end{array}$ \\
\hline Retained earnings / capital & $\begin{array}{c}0.106 \\
(0.106)\end{array}$ & $\begin{array}{c}0.147 \\
(0.118)\end{array}$ & $\begin{array}{c}0.299 \\
(0.139)^{* *}\end{array}$ \\
\hline 3\% Individual Owner & $\begin{array}{c}0.721 \\
(0.167)^{* * *}\end{array}$ & & \\
\hline $3 \%$ Insurance Owner & $\begin{array}{c}-0.267 \\
(0.074)^{* * *}\end{array}$ & & \\
\hline 3\% Director Owner & $\begin{array}{c}0.017 \\
(0.020)\end{array}$ & & \\
\hline 7\% Individual Owner & & $\begin{array}{l}0.298 \\
(0.179)^{*}\end{array}$ & \\
\hline $7 \%$ Insurance Owner & & $\begin{array}{l}-0.225 \\
(0.402)\end{array}$ & \\
\hline $7 \%$ Director Owner & & $\begin{array}{c}0.127 \\
(0.068)^{*}\end{array}$ & \\
\hline $\begin{array}{l}\text { Largest Individual Owner } \\
(\%)\end{array}$ & & & $\begin{array}{c}3.457 \\
(1.006)^{* * *}\end{array}$ \\
\hline $\begin{array}{l}\text { Largest Insurance Owner } \\
(\%)\end{array}$ & & & $\begin{array}{c}1.583 \\
(1.549)\end{array}$ \\
\hline Director Owner (\%) & & & $\begin{array}{c}0.761 \\
(0.324)^{* *}\end{array}$ \\
\hline Constant & $\begin{array}{c}-0.987 \\
(0.465)^{* *}\end{array}$ & $\begin{array}{l}0.419 \\
(0.284)\end{array}$ & $\begin{array}{l}-0.370 \\
(0.438)\end{array}$ \\
\hline Chi-square & $116.8^{* * *}$ & $13.3^{*}$ & $21.3^{* * *}$ \\
\hline
\end{tabular}

$-43-$ 
Table 4

Robustness checks

Determinants of firm value

\begin{tabular}{|c|c|c|}
\hline $3 \%$ owners & $7 \%$ owner & Large owner \% \\
\hline \multicolumn{3}{|c|}{$\begin{array}{l}\text { Notes: } 206 \text { observations. Dependent variable is Q. }{ }^{* * *} \text { implies } \mathrm{p}<0.01 ; * * \text { implies } \mathrm{p}<0.05 \text {; and } * \text { implies } \mathrm{p}<0.10 \\
\text { Robust standard errors clustered on bank in parentheses. } \\
\text { Sources: Authors calculation from data described in Data Appendix }\end{array}$} \\
\hline
\end{tabular}


Table 5

3SLS estimates - Tobin's Q and Director Loans

\begin{tabular}{|c|c|c|}
\hline & \multicolumn{2}{|c|}{ Dependent variable $=$ Tobin's $Q$} \\
\hline $\ln$ (Assets) & $\begin{array}{c}0.029 \\
(0.027)\end{array}$ & $\begin{array}{c}0.040 \\
(0.020)^{* *}\end{array}$ \\
\hline $\ln$ (Directors) & $\begin{array}{l}-0.139 \\
(0.124)\end{array}$ & $\begin{array}{l}-0.055 \\
(0.128)\end{array}$ \\
\hline $5 \%$ Individual Owner & $\begin{array}{c}0.092 \\
(0.102)\end{array}$ & $\begin{array}{c}0.123 \\
(0.048)^{* * *}\end{array}$ \\
\hline $5 \%$ Insurance Owner & $\begin{array}{c}0.160 \\
(0.076)^{* *}\end{array}$ & $\begin{array}{c}0.207 \\
(0.115)^{*}\end{array}$ \\
\hline Loans to directors / Loans & $\begin{array}{c}-0.933 \\
(0.281)^{* * *}\end{array}$ & $\begin{array}{c}-0.771 \\
(0.225)^{* * *}\end{array}$ \\
\hline Last dividend (\%) & $\begin{array}{l}-0.010 \\
(0.007)\end{array}$ & $\begin{array}{c}-0.017 \\
(0.007)^{* *}\end{array}$ \\
\hline Nonperforming loans / loans & $\begin{array}{c}-0.312 \\
(0.110)^{* * *}\end{array}$ & $\begin{array}{l}-0.025 \\
(0.131)\end{array}$ \\
\hline Retained earnings / capital & $\begin{array}{c}0.087 \\
(0.145)\end{array}$ & $\begin{array}{l}-0.009 \\
(0.133)\end{array}$ \\
\hline Constant & $\begin{array}{c}1.012 \\
(0.285)^{* * *}\end{array}$ & $\begin{array}{c}0.692 \\
(0.220)^{* * *}\end{array}$ \\
\hline & Dependent & ors / Loans \\
\hline $5 \%$ Individual Owner & $\begin{array}{l}-0.092 \\
(0.159)\end{array}$ & $\begin{array}{c}0.296 \\
(0.108)^{* * *}\end{array}$ \\
\hline $5 \%$ Insurance Owner & $\begin{array}{c}0.003 \\
(0.156)\end{array}$ & $\begin{array}{c}-1.239 \\
(0.277)^{* * *}\end{array}$ \\
\hline $\ln$ (Assets) & $\begin{array}{c}-0.062 \\
(0.033)^{*}\end{array}$ & $\begin{array}{c}-0.073 \\
(0.037)^{* *}\end{array}$ \\
\hline $\ln$ (Directors) & $\begin{array}{c}0.201 \\
(0.173)\end{array}$ & $\begin{array}{c}0.257 \\
(0.183)\end{array}$ \\
\hline Boston & $\begin{array}{c}0.040 \\
(0.067)\end{array}$ & $\begin{array}{c}0.250 \\
(0.086)^{* * *}\end{array}$ \\
\hline$\%$ Shares votes at last meeting & -- & $\begin{array}{c}-0.150 \\
(0.089)^{*}\end{array}$ \\
\hline
\end{tabular}


Table 5

3SLS estimates - Tobin's Q and Director Loans

\begin{tabular}{|c|c|c|}
\hline Constant & $\begin{array}{c}0.571 \\
(0.279)^{* *}\end{array}$ & $\begin{array}{c}0.418 \\
(0.373)\end{array}$ \\
\hline Observations & 206 & 115 \\
\hline \multicolumn{3}{|c|}{$\begin{array}{l}\text { Notes: } * * * \text { implies } \mathrm{p}<0.01 ; * * \text { implies } \mathrm{p}<0.05 \text {; and } * \text { implies } \mathrm{p}<0.10 \text {. Robust standard errors clustered on bank in } \\
\text { parentheses. } \\
\text { Sources: Authors calculation from data described in Data Appendix }\end{array}$} \\
\hline
\end{tabular}




\section{Appendix Table A1}

3SLS estimates - Board Size, Individual and Institutional Investors

\begin{tabular}{|c|c|c|c|c|}
\hline & $5 \%$ owners & $3 \%$ owners & $7 \%$ owners & Large owners $(\%)$ \\
\hline & \multicolumn{4}{|c|}{ Dependent variable $=\ln$ (directors) } \\
\hline Loans / assets & $\begin{array}{c}0.556 \\
(0.269)^{* *}\end{array}$ & $\begin{array}{c}0.243 \\
(0.563)\end{array}$ & $\begin{array}{l}-0.365 \\
(0.286)\end{array}$ & $\begin{array}{c}0.435 \\
(0.226)^{* *}\end{array}$ \\
\hline $\ln$ (assets) & $\begin{array}{l}-0.029 \\
(0.062)\end{array}$ & $\begin{array}{l}-0.485 \\
(0.337)\end{array}$ & $\begin{array}{c}0.081 \\
(0.053)\end{array}$ & $\begin{array}{c}0.088 \\
(0.035)^{* *}\end{array}$ \\
\hline Boston & $\begin{array}{c}-0.316 \\
(0.129)^{* *}\end{array}$ & $\begin{array}{l}-0.156 \\
(0.125)\end{array}$ & $\begin{array}{c}0.379 \\
(0.222)^{*}\end{array}$ & $\begin{array}{c}-0.276 \\
(0.076) * * *\end{array}$ \\
\hline Individual owners & $\begin{array}{c}-0.855 \\
(0.388) * *\end{array}$ & $\begin{array}{c}-4.471 \\
(2.034)^{* *}\end{array}$ & $\begin{array}{c}1.033 \\
(0.392)^{* * *}\end{array}$ & $\begin{array}{c}-4.768 \\
(1.470)^{* * *}\end{array}$ \\
\hline Insurance company & $\begin{array}{c}-0.790 \\
(0.457)^{*}\end{array}$ & $\begin{array}{c}1.487 \\
(0.794)^{*}\end{array}$ & $\begin{array}{c}-6.562 \\
(1.003)^{* * *}\end{array}$ & $\begin{array}{c}-9.415 \\
(4.437)^{* *}\end{array}$ \\
\hline Bank age & $\begin{array}{c}-0.020 \\
(0.006) * * *\end{array}$ & $\begin{array}{l}-0.006 \\
(0.005)\end{array}$ & $\begin{array}{l}-0.005 \\
(0.005)\end{array}$ & $\begin{array}{c}-0.010 \\
(0.003) * * *\end{array}$ \\
\hline Bank age squared & $\begin{array}{c}0.0003 \\
(0.00008)^{* * *}\end{array}$ & $\begin{array}{c}0.00007 \\
(0.00008)\end{array}$ & $\begin{array}{c}0.00002 \\
(0.00008)\end{array}$ & $\begin{array}{c}0.0001 \\
(0.00006)^{* *}\end{array}$ \\
\hline Tobins Q & $\begin{array}{c}3.413 \\
(1.052)^{* * *}\end{array}$ & $\begin{array}{c}6.102 \\
(3.808)^{*}\end{array}$ & $\begin{array}{c}-2.158 \\
(0.665)^{* * *}\end{array}$ & $\begin{array}{c}1.248 \\
(0.801)\end{array}$ \\
\hline \multirow[t]{2}{*}{ Constant } & $\begin{array}{l}-0.597 \\
(1.087)\end{array}$ & $\begin{array}{c}5.868 \\
(2.696)^{* *}\end{array}$ & $\begin{array}{c}3.262 \\
(1.059)^{* * *}\end{array}$ & $\begin{array}{c}0.050 \\
(0.981)\end{array}$ \\
\hline & \multicolumn{4}{|c|}{ Dependent variable $=$ individual blockholder } \\
\hline Boston & $\begin{array}{l}-0.146 \\
(0.116)\end{array}$ & $\begin{array}{c}0.041 \\
(0.049)\end{array}$ & $\begin{array}{c}-0.371 \\
(0.112)^{* * *}\end{array}$ & $\begin{array}{l}-0.180 \\
(0.013)\end{array}$ \\
\hline $\ln (\operatorname{Par} \$$ share $)$ & $\begin{array}{c}-0.184 \\
(0.071)^{* * *}\end{array}$ & $\begin{array}{l}-0.030 \\
(0.059)\end{array}$ & $\begin{array}{l}-0.080 \\
(0.108)\end{array}$ & $\begin{array}{c}-0.025 \\
(0.009)^{* * *}\end{array}$ \\
\hline $\ln$ (Assets) & $\begin{array}{c}-0.119 \\
(0.062)^{*}\end{array}$ & $\begin{array}{c}-0.120 \\
(0.029)^{* * *}\end{array}$ & $\begin{array}{l}-0.011 \\
(0.060)\end{array}$ & $\begin{array}{c}-0.013 \\
(0.007)^{*}\end{array}$ \\
\hline \multirow[t]{2}{*}{ Constant } & $\begin{array}{c}2.999 \\
(0.838)^{* * *}\end{array}$ & $\begin{array}{c}2.639 \\
(0.447)^{* * *}\end{array}$ & $\begin{array}{c}0.963 \\
(0.928)\end{array}$ & $\begin{array}{c}0.359 \\
(0.098)^{* * *}\end{array}$ \\
\hline & \multicolumn{4}{|c|}{ Dependent variable $=$ institutional blockholder } \\
\hline Boston & $\begin{array}{c}0.143 \\
(0.077)^{*}\end{array}$ & $\begin{array}{c}0.071 \\
(0.106)\end{array}$ & $\begin{array}{c}0.031 \\
(0.034)\end{array}$ & $\begin{array}{c}0.008 \\
(0.004)^{*}\end{array}$ \\
\hline $\ln$ (Assets) & $\begin{array}{c}-0.087 \\
(0.041)^{* *}\end{array}$ & $\begin{array}{c}0.013 \\
(0.058)\end{array}$ & $\begin{array}{l}-0.021 \\
(0.019)\end{array}$ & $\begin{array}{l}-0.002 \\
(0.002)\end{array}$ \\
\hline
\end{tabular}


Appendix Table A1

3SLS estimates - Board Size, Individual and Institutional Investors

\begin{tabular}{crrrc}
\hline & $\mathbf{5 \%}$ owners & $\mathbf{3 \%}$ owners & 7\% owners & Large owners (\%) \\
\hline \multirow{2}{*}{ Constant } & 1.220 & 0.085 & 0.286 & 0.045 \\
& $(0.529)^{* *}$ & $(0.745)$ & $(0.238)$ & $(0.031)$
\end{tabular}

Notes: 206 observations. $* * *$ implies $\mathrm{p}<0.01$; $* *$ implies $\mathrm{p}<0.05$; and $*$ implies $\mathrm{p}<0.10$. Robust standard errors clustered on bank in parentheses.

Sources: Authors calculation from data described in Data Appendix 